\title{
Analisa pengaruh cuaca terhadap losses dan penurunan effisiensi akibat korona pada sutt $150 \mathrm{kV}$
}

\author{
Arfita Yuana Dewi ${ }^{1)^{*}}$, Asnal Effendi $^{2)}$, Erhaneli $^{3)}$, Febtria Gita $^{4)}$ \\ ${ }^{1234}$ Fakultas Teknik, Institut Teknologi Padang, Padang, Sumatera Barat, Indonesia \\ arfitarachman.itp@gmail.com, asnal.effendi@gmail.com, erhanelimarzuki@gmail.com, febtriagita@gmail.com
}

\begin{abstract}
ABSTRAK
Saluran transmisi merupakan bagian yang tidak terpisahkan dalam penyaluran energi listrik ke konsumen. Saluran yang memiliki tegangan tinggi ini bertujuan untuk memperkecil rugi- rugi daya (losses), tetapi dengan tingginya tegangan akan menimbulkan permasalahan baru yaitu timbulnya korona yang akan menyebabkan timbulnya losses, noise, interferensi terhadap saluran komunikasi. Rugi-rugi korona dipengaruhi oleh jari-jari kawat, jarak antar kawat, keadaan permukaan kawat dan pengaruh temperatur atau cuaca. Tujuan dari penelitian ini adalah melihat pengaruh cuaca terhadap losses dan penurunan effisiensi yang diakibatkan oleh korona pada Saluran Udara Tegangan Tinggi (SUTT) $150 \mathrm{kV}$ pada GI Payakumbuh - GI Koto Panjang dengan panjang saluran $84,84 \mathrm{~km}$. Hasil penelitian pada cuaca baik losses akibat korona tertinggi pada suhu maksimum sebesar $755,92 \mathrm{~kW}$ dan terendah pada suhu udara minimum sebesar 702,47 kW. Sedangkan effisiensi tertinggi terjadi pada suhu minimum sebesar 96,89\%. terendah terjadi pada suhu maksimum sebesar 96,62\%. Dengan adanya penurunan effisiensi maka losses yang terjadi mencapai 3,38\%.Pada cuaca buruk losses yang disebabkan oleh korona tertinggi pada suhu maksimum sebesar 262,15 kW. Dengan adanya penurunan effisiensi maka losses yang terjadi akibat korona mencapai 1,02 \% , yang masih dalam keadaan stabil dimana belum melebihi Standar SPLN No.72 Tahun 1987 yakni sebesar 5\%, namun untuk meminimalisir losses dapat dilakukan dengan memperkecil nilai tahanan kawat atau menambah jumlah kawat per-phasa.
\end{abstract}

Kata kunci: Losses, effisiensi, korona, temperatur, transmisi.

\begin{abstract}
The transmission line is a part of electrical power system in distributing electrical energy to consumers. This line aims to minimize power losses, but by increasing the voltage it will cause new problems, namely corona, it caused power losses, noise and radio interference. Corona losses are affected by the radius of the wire, the distance between the wires, the state of the wire surface and the influence of temperature or weather. The purpose of this study was to see the effect of weather on power losses and a decrease in efficiency caused by the corona at $150 \mathrm{kV}$ SUTT of Payakumbuh Substation - Koto Panjang Substation with line length is 84.84 kms. The results of research on good weather are the highest power losses due to corona at a maximum temperature of $755.92 \mathrm{~kW}$ and the lowest at a minimum air temperature of $702.47 \mathrm{~kW}$. While the highest efficiency occurs at a minimum temperature of $96.89 \%$. the lowest occurred at a maximum temperature of $96.62 \%$. With a decrease in efficiency, the power losses that occur due to corona reach 3.38\%. In bad weather the power losses caused by corona are highest at a maximum temperature of $262.15 \mathrm{~kW}$. With a decrease in efficiency, the power losses that occur due to corona reach $1.02 \%$, which is still in a stable state which has not exceeded the SPLN Standard No.72 of 1987, which is 5\%, but to minimize losses it can be done by reducing the value of the wire resistance or increasing the number of wires per phase.
\end{abstract}

Keywords: Power losses, efficiency, corona, temperature, transmission.

diunggah: Oktober 2021, direvisi: November 2021, diterima: Desember 2021, dipublikasi: Desember 2021 Copyright (c) 2021 Arfita Yuana Dewi, Asnal Effendi, Erhaneli , Febtria Gita This is an open access article under the CC-BY license 


\section{PENDAHULUAN}

Penyaluran daya listrik dari sumber pembangkitan ke konsumen ada kalanya akan mengalami rugi daya (losses) ataupun jatuh tegangan(Manik, 2013)(Dewi, 2020). Untuk mengatasi hal tersebut dapat dilakukan dengan cara menaikkan tegangan ke tingkat tegangan yang lebih tinggi.(Kosasih, 2017). Meskipun dengan menaikkan tegangan transmisi akan mengurangi losses, tetapi ada batasnya dimana sudah diatur oleh pihak penyedia listrik yaitu Standar SPLN No.72 Tahun 1987 yakni sebesar 5\%.(Hariyadi, 2017) dan (Dewantara et al., 2018). Menaikkan tegangan ke tingkat tegangan yang lebih tinggi dapat menimbulkan gejala korona pada kawat transmisi. Korona pada transmisi dapat menimbulkan hilangnya daya dan juga gangguan terhadap komunikasi radio (Febry Johan Palasworo, 2019) dan (Barrett et al., 1999)

Saluran transmisi yang merupakan kawat penghantar dapat menimbulkan terjadinya peristiwa korona, dengan tahapan sebagai berikut: . Pertama kali, kawat terlihat bercahaya, mengeluarkan suara mendesis ( hissing) dan berbau ozon. Warna cahaya adalah ungu (violet) muda(Rusdi, 2019). Berikutnya bila tegangan dinaikkan terus, maka karakteristik diatas makin nyata terlihat, terutama pada bagian yang kasar, runcing atau kotor, cahaya bertambah besar dan terang. Selanjutnya terjadi busur api yang berarti Korona mengeluarkan panas, yang dibuktikan melaului pengukuran menggunakan Watt meter. Dalam keadaan udara lembab, korona menghasilkan Asam Nitrogen (nitrous acid), yang menyebabkan kawat menjadi berkarat bila kehilangan daya cukup besar(Douglass \& Thrash, 2012) dan (ANGGARA, 2019).

Berdasarkan ANSI (American National Standards Institute) korona merupakan fenomena terjadinya peluahan sebagian (partial discharge) ditandai berupa cahaya violet akibat terjadinya ionisasi udara di sekitar permukaan konduktor ketika gradien tegangan permukaan konduktor melebihi nilai kuat medan listrik disruptifnya. Yang ditandai dengan suara mendesis dan berbau ozone pada sekitar saluran transmisi (Manullang, 2020) dan (Aykas, 2012) dan (Gorur et al., 1995)

Beberapa gangguan akibat korona seperti rugi-rugi daya (losses), kerusakan pada bahan isolasi, noise dan interferensi radio.(Masarrang et al., 2019) Pada saluran transmisi yaitu pada luas penampang kawat, konfigurasi atau pola susunan kawat, keadaan permukaan kawat, suhu dan cuaca sangat berpengaruh terhadap terjadinya korona..(Vijayan \& Patil, 2010) dan (A.N. Afandi, 2011). Hujan adalah faktor cuaca yang sangat menentukan. Pada saluran transmisi yang memiliki curah hujan yang lebih tinggi, rugi-rugi korona pada saluran transmisi akan lebih besar dari pada saluran yang memiliki curah hujan yang rendah.(Saraswati et al., 2012)(Olsen \& Edwards, 2002) (Olsen \& Edwards, 2002). Selain hujan, kelembaban udara, suhu, tekanan udara dan medan listrik bumi juga mempengaruhi besar rugi-rugi korona pada saluran transmisi.(Nadzirin et al., 2012). Rugi-rugi korona akan bertambah dengan cepat oleh hujan dan kabut. Pada saluran transmisi dengan tegangan diatas 100 kV gejala korona sudah mulai serius (Yu et al., 2013) dan (Cimini \& Fonseca, 2013)

Terjadinya korona disebabkan oleh kondisi atmosfer, diameter saluran/konduktor transmisi, permukaannya, tegangan, dan jarak kawat antar fasa. Cara untuk menentukan atau menghitungnya telah di lakukan oleh beberapa peneliti diantaranya " PEEK" Rumus korona PEEK didapatkan dari percobaan menggunakan sebuah kawat dengan panjang 300 meter dan menggunakan sebuah trafo uji $200 \mathrm{kV}, 1$ fasa. Kemudian dihasilkan rumus rumus CorollRockwell dan Peterson yang dianggap cukup dapat dipercaya, terutama untuk hilang korona rendah (kurang dari $5 \mathrm{~kW}$ per mil kawat 3 fasa) (Dewi, 2020) dan (Alius \& Hariyanto, 2014).

Berdasarkan hal diatas, penulis melakukan penelitian dengan perumusan masalah untuk mendapatkan seberapa besar pengaruh korona dengan kondisi cuaca daerah tropis pada 
saluran transmisi terhadap persentasi rugi-rugi daya dan penurunan efisiensi penyaluran daya listrik, dengan mengacu pada Standar SPLN No.72 Tahun 1987 yakni tidak boleh melebihi 5\%. Dengan mengambil lokasi yaitu pada Saluran Udara Tegangan Tinggi $150 \mathrm{kV}$ GI Payakumbuh ke GI Koto Panjang, dengan data seperti yang ditunjukkan pada Tabel 1 berikut :

Tabel 1. Data penelitian

\begin{tabular}{|l|l|l|}
\hline No. & Jenis Data & Nilai dan Satuan \\
\hline 1. & Tegangan Sistem & $150 \mathrm{kV}$ \\
\hline 2. & Saluran & Transmisi GI Payakumbuh-GI Koto Panjang \\
\hline 3. & Panjang Saluran & $84,84 \mathrm{~km}$ \\
\hline 4. & Jenis Kawat Penghantar & $\mathrm{ACSR} / 1 \times 340 / 30 \mathrm{~mm}^{2}$ \\
\hline 5. & Luas Penampang Luar & $369,1 \mathrm{~mm}^{2}$ \\
\hline 6. & Diameter Luar & $24,99 \mathrm{~m} \mathrm{~m}$ \\
\hline 7. & Jarak Antar Fasa & $4300 \mathrm{~m} \mathrm{~m}$ \\
\hline 8. & Jumlah Kawat Fasa & 1 Buah \\
\hline 9. & Banyak Urat Aluminium & 48 Buah \\
\hline 10. & Banyak Urat untuk steel & 7 Buah \\
\hline
\end{tabular}

\section{METODE}

Jenis penelitian yang dilakukan adalah melihat bagaimana pengaruh cuaca terhadap losses dan penurunan effisiensi yang diakibatkan oleh korona yang terjadi pada Saluran Udara Tegangan Tinggi (SUTT) $150 \mathrm{kV}$ GI Payakumbuh ke GI Koto Panjang dengan panjang saluran 84,84 km (PT PLN (Persero), 2014). Penelitian ini dilakukan pada kondisi cuaca baik dan cuaca buruk (hujan) dengan suhu rata-rata $25,9^{\circ} \mathrm{C}$, suhu maksimum $27,4^{0} \mathrm{C}$ dan suhu minimum $25,2^{\circ} \mathrm{C}$.

Proses pelaksanaan penelitian ini disajikan seperti pada Gambar 1 berikut :

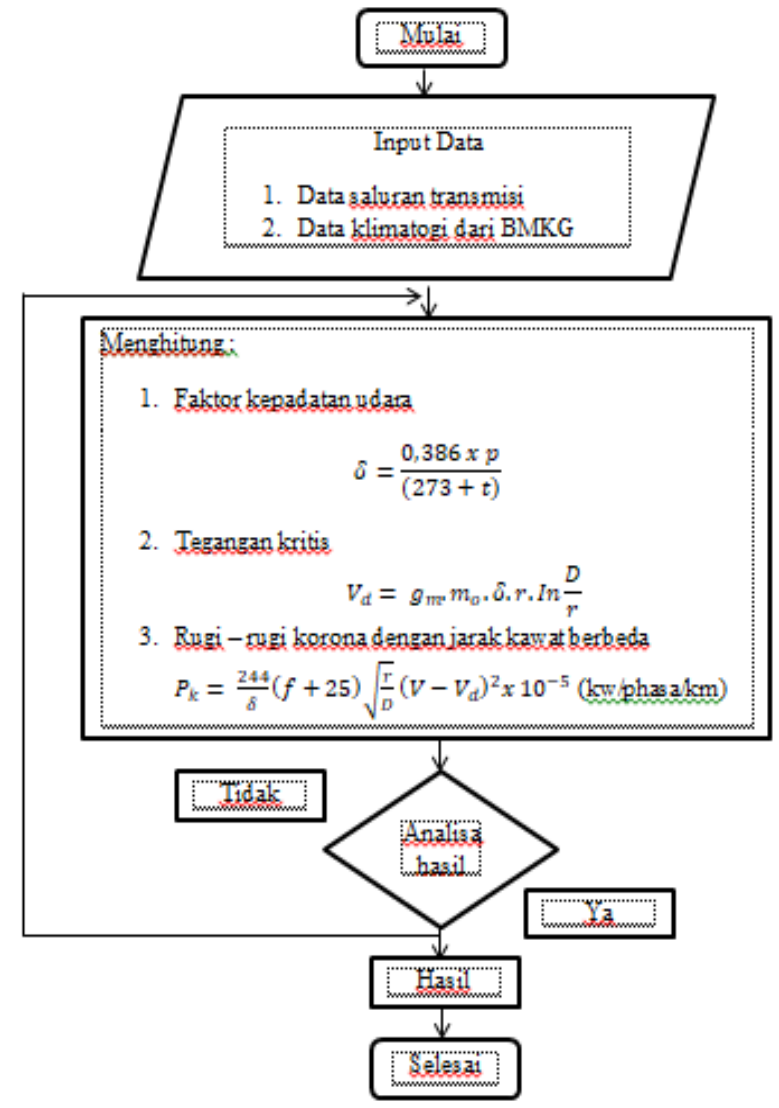

Gambar 1. Diagram alir penelitian 


\section{HASIL DAN PEMBAHASAN}

Untuk memenuhi kebutuhan data dalam penelitian ini maka sebagai aplikasi atau lokasi kajian untuk pengambilan data adalah Saluran Udara Tegangan Tinggi (SUTT) 150 kV GI Payakumbuh - GI Koto Panjang dengan panjang saluran 84,84 km seperti yang ditunjukkan pada Gambar 2 yaitu Peta lokasi Saluran Udara Tegangan Tinggi SUTT $150 \mathrm{kV}$ GI Payakumbuh- GI Koto Panjang. Sedangkan Gambar 3 adalah single line diagram Saluran Udara Tegangan Tinggi (SUTT) 150 kV GI Payakumbuh - GI Koto Panjang

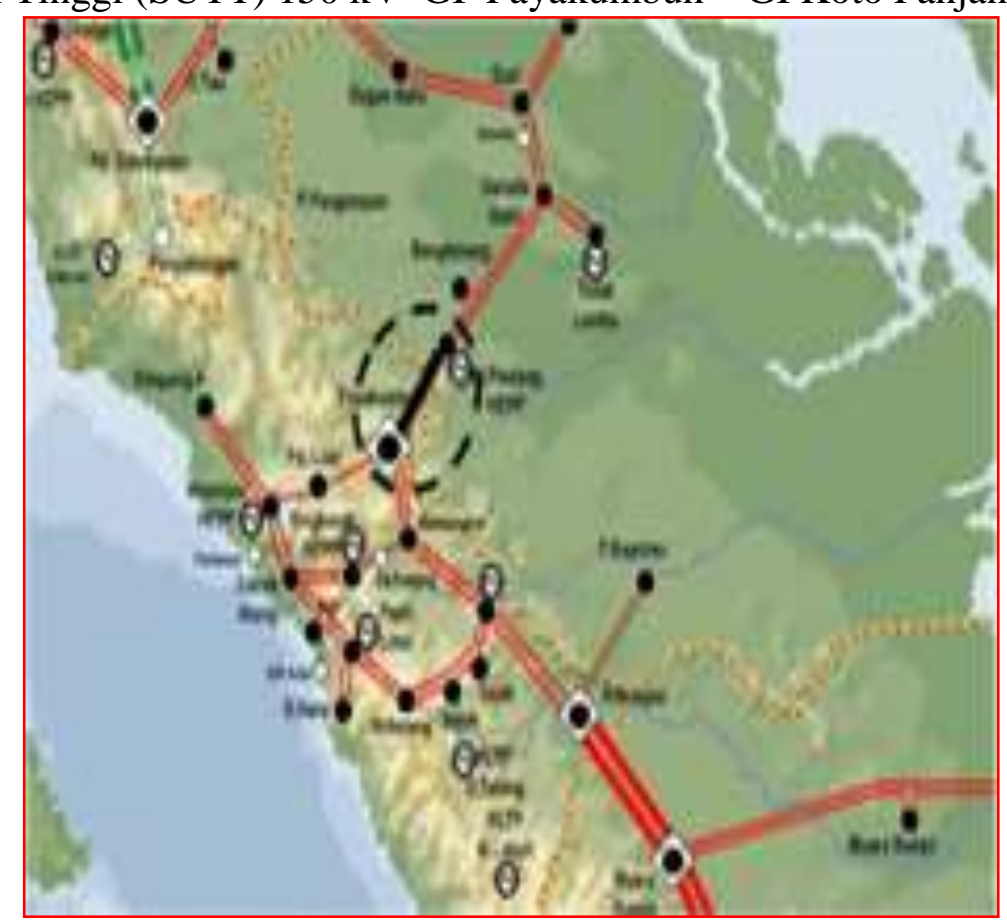

Gambar 2. Peta lokasi SUTT 150 kV

Data teknis transmisi $150 \mathrm{kV}$ penghantar Payakumbuh - Koto Panjang Tahun 2020 diperoleh dari PT.PLN (Persero) UIP3BS UPT Padang ULTG Payakumbuh. Sedangkan data curah hujan dan suhu (temperatur) didapat dari BMKG Stasiun Klimatologi Padang Pariaman.

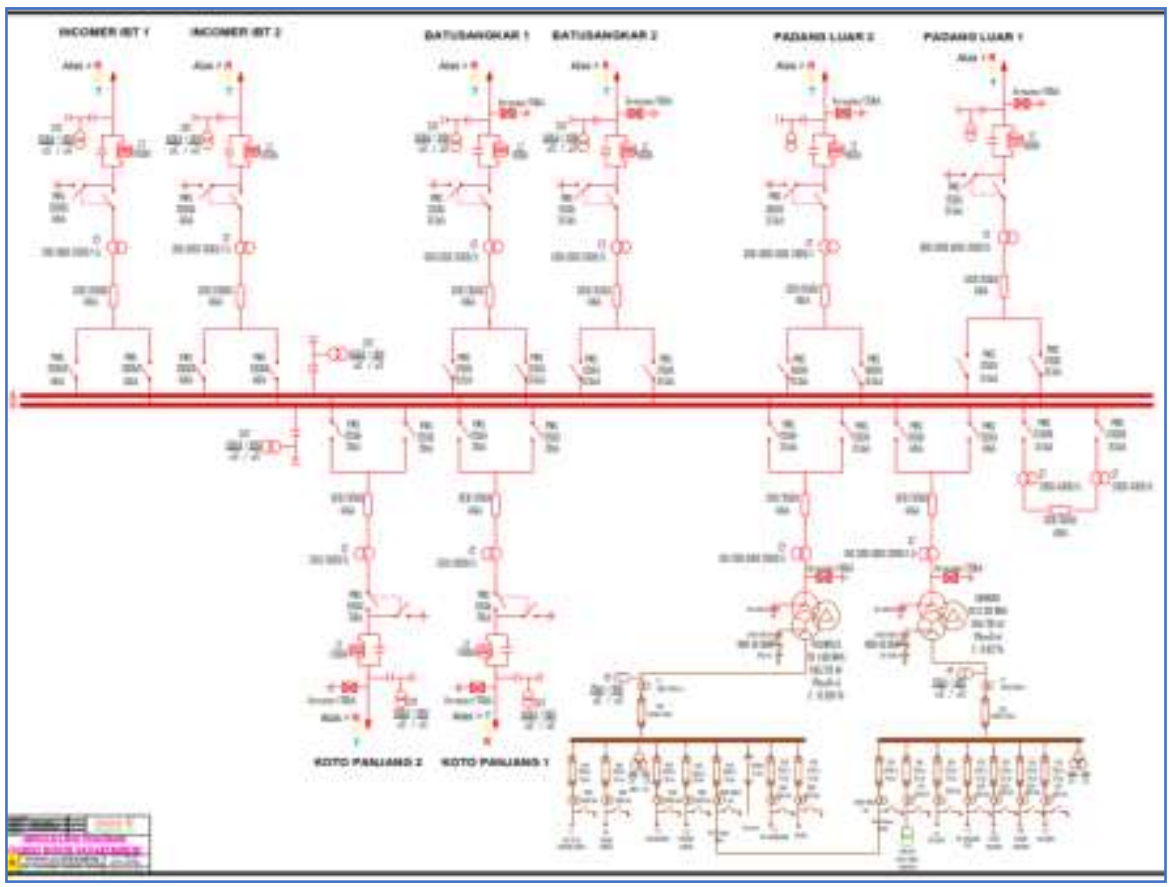

Gambar 3. Single line diagram gardu induk payakumbuh 
Untuk dapat memperlihatkan hasil perhitungan (seperti yang ditunjukkan pada gambar 1), secara keseluruhannya maka dirangkum ke dalam bentuk tabel 2 di bawah ini.:

Tabel 2. Hasil perhitungan pada cuaca baik

\begin{tabular}{|l|l|l|l|l|}
\hline Keadaan suhu & \multicolumn{1}{|c|}{$\begin{array}{c}\text { Suhu } \\
\left({ }^{\circ} \mathrm{C}\right)\end{array}$} & $\begin{array}{c}\text { Rugi-rugi } \\
\text { daya korona } \\
(\mathrm{kW})\end{array}$ & $\begin{array}{c}\text { Penurunan } \\
\text { Effisiensi } \\
(\%)\end{array}$ & $\begin{array}{c}\text { Rugi daya } \\
\text { korona } \\
(\%)\end{array}$ \\
\hline Suhu Udara Rata-rata & 25,9 & 715,20 & 96.80 & 3,2 \\
\hline Suhu Maksimum & 27,4 & 755,92 & 96,62 & 3,38 \\
\hline Suhu Minimum & 25,2 & 702,47 & 96,89 & 3,11 \\
\hline
\end{tabular}

Berdasarkan hasil yang ditunjukkan tabel 2 diatas, karakterisrik pengaruh temperatur terhadap rug-rugi daya dan nilai efisiensi akibat korona seperti yang ditunjukkan pada gambar 4 berikut :

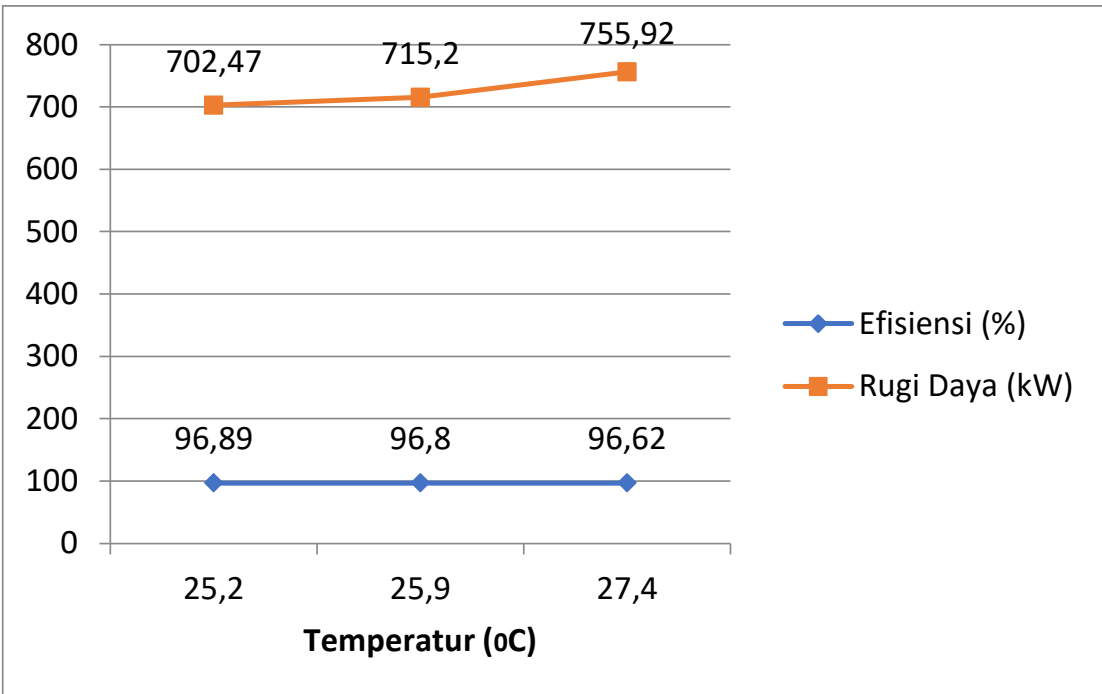

\section{Gambar 4. Pengaruh temperatur terhadap rug-rugi daya dan nilai efisiensi akibat korona}

Pada tabel 2. dan gambar 4 diatas, suhu udara rata-rata $25,9^{\circ} \mathrm{C}$ didapatkan losses yang diakibatkan korona adalah 715,20 kW dengan penurunan effisiensi 96,80\%, sehingga dengan adanya penurunan effisiensi maka losses akibat korona didapat 3,2\%. Pada suhu udara maksimum $27,4^{\circ} \mathrm{C}$ didapatkan losses yang diakibatkan korona adalah $755,92 \mathrm{~kW}$ dengan penurunan effisiensi 96,62\%, sehingga dengan adanya penurunan effisisensi tersebut maka losses akibat korona adalah $3.38 \%$. Pada suhu udara minimum $25,2^{\circ} \mathrm{C}$ didapatkan losses yang diakibatkan korona adalah 702,47 kW dengan penurunan effisiensi 96,89\%, sehingga dengan adanya penurunan effisiensi maka losses akibat korona adalah $3.11 \%$.

Dari pembahasan diatas dapat disimpulkan bahwa pada cuaca baik losses yang disebabkan oleh korona tertinggi pada suhu maksimum sebesar 755,92 $\mathrm{kW}$ dan terendah terdapat pada suhu udara minimum sebesar $702,47 \mathrm{~kW}$. Sedangkan effisiensi tertinggi terjadi pada suhu minimum sebesar 96,89\%. Dan terendah terjadi pada suhu maksimum sebesar 96,62 \%. Dengan adanya penurunan effisiensi maka losses yang terjadi akibat korona mencapai $3,38 \%$.

Dan hasil perhitungan secara keseluruhannya kondisi cuaca buruk di rangkum ke dalam tabel 3 sebagai berikut : 
Tabel 3. Rekapitulasi hasil perhitungan pada cuaca buruk (hujan)

\begin{tabular}{|l|c|c|c|c|}
\hline \multicolumn{1}{|c|}{ Keadaan suhu } & $\begin{array}{c}\text { Suhu } \\
\left({ }^{\circ} \mathrm{C}\right)\end{array}$ & $\begin{array}{c}\text { Rugi-rugi } \\
\text { daya korona } \\
(\mathrm{kW})\end{array}$ & $\begin{array}{c}\text { Penurunan } \\
\text { Effisiensi } \\
(\%)\end{array}$ & $\begin{array}{c}\text { Rugi daya korona } \\
(\%)\end{array}$ \\
\hline Suhu Udara Rata-rata & 25,9 & 226,26 & 98,98 & 1,02 \\
\hline Suhu Maksimum & 27,4 & 262,15 & 98,82 & 1,18 \\
\hline Suhu Minimum & 25,2 & 243,83 & 98,91 & 1,09 \\
\hline
\end{tabular}

Berdasarkan hasil yang ditunjukkan tabel 3 diatas, karakterisrik pengaruh temperatur terhadap rug-rugi daya dan nilai efisiensi akibat korona seperti yang ditunjukkan pada gambar 5 berikut :

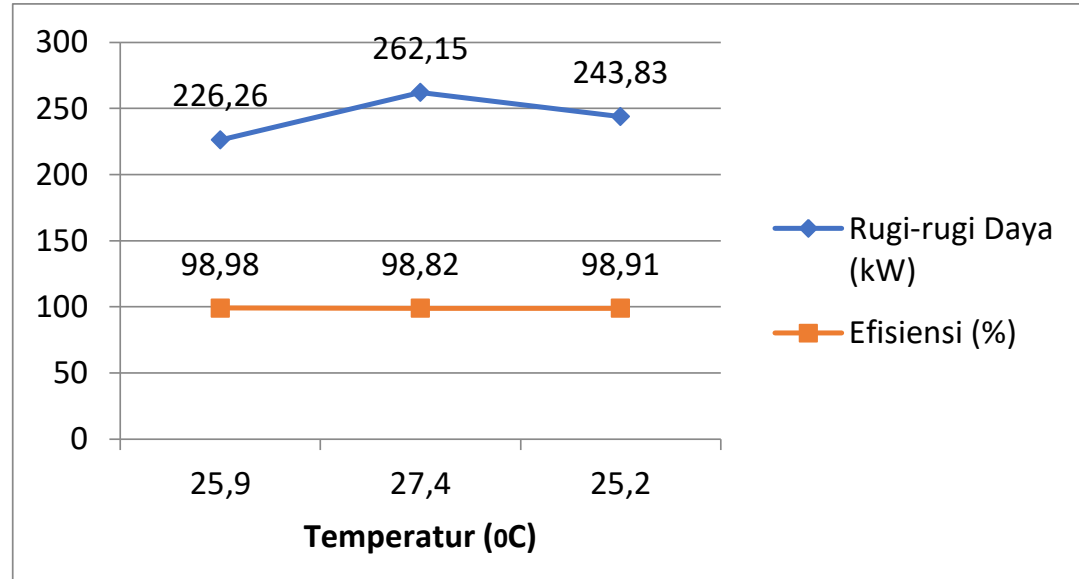

\section{Gambar 5. Pengaruh temperatur terhadap rug-rugi daya dan nilai efisiensi akibat korona}

Tabel 3 dan Gambar 5 menunjukkan rekapitulasi hasil perhitungan losses yang diakibatkan oleh korona dan penurunan effisiensi pada SUTT $150 \mathrm{kV}$ dari GI Payakumbuh ke GI Koto Panjang dengan panjang saluran $84,84 \mathrm{~km}$ pada keadaan cuaca buruk dengan tiga kondisi suhu udara ( suhu rata-rata, suhu maksimum dan suhu minimum).

Pada suhu udara rata-rata $25,9^{\circ} \mathrm{C}$ didapatkan losses yang diakibatkan korona adalah $226,26 \mathrm{~kW}$ dengan penurunan effisiensi 98,98 \%, sehingga dengan adanya penurunan effisiensi maka losses akibat korona didapat $1,02 \%$. Pada suhu udara maksimum $27,4^{\circ} \mathrm{C}$ didapatkan losses yang diakibatkan korona adalah $262,15 \mathrm{~kW}$ dengan penurunan effisiensi $98,82 \%$, sehingga dengan adanya penurunan effisisensi tersebut maka losses akibat korona adalah 1,18\%. Pada suhu udara minimum $25,2^{\circ} \mathrm{C}$ didapatkan losses yang diakibatkan korona adalah $243,83 \mathrm{~kW}$ dengan penurunan effisiensi $98,91 \%$, sehingga dengan adanya penurunan effisiensi maka losses akibat korona adalah 1,08\%.

Dari pembahasan diatas dapat disimpulkan bahwa pada cuaca buruk losses yang disebabkan oleh korona tertinggi pada suhu maksimum sebesar $262,15 \mathrm{~kW}$ dan losses terendah terdapat pada suhu udara rata-rata sebesar $226,26 \mathrm{~kW}$. Sedangkan effisiensi tertinggi terjadi pada suhu rata-rata sebesar $98,98 \%$. dan terendah terjadi pada suhu maksimum sebesar 98,82 \%. Dengan adanya penurunan effisiensi maka losses yang terjadi akibat korona mencapai $1,02 \%$.

Untuk mengetahui seberapa besar pengaruh losses yang diakibatkan oleh korona, maka berikutnya dilakukan analisa nilai pengaruh rugi daya teknis pada transmisi tegangan tinggi terutama pada SUTT $150 \mathrm{kV}$ GI Payakumbuh ke GI Koto Panjang dengan panjang saluran $84,84 \mathrm{~km}$, maka dilakukan perhitungan losses jika tanpa memperhitungkan korona 
pada saluran kemudian membandingkannya dengan hasil perhitungan losses dengan memperhitungkan pengaruh korona.

Dengan menggunakan persamaan berikut, maka losses pada transmisi tegangan tinggi adalah :

$$
P_{\text {Losses }}=I^{2} \cdot R \mathrm{~kW}
$$

Dimana dari data lapangan :

$$
\begin{aligned}
& I=88 \text { Amper } \\
& I^{2}=88^{2}=7.744 \text { Amper }
\end{aligned}
$$

Untuk menentukan nilai $\mathrm{R}$ (tahanan) dapat menggunakan persamaan berikut :

$$
R=\rho \frac{L}{A} \Omega
$$

Dimana : $\quad L=84,84 \mathrm{~km}=84,84 \times 10^{5} \mathrm{~cm}$

$$
\begin{aligned}
\rho & =2,89 \times 10^{-6} \\
A & =\pi r^{2}=3,14(12,5)^{2} \\
& =39,25 \mathrm{~mm}^{2}
\end{aligned}
$$

Maka : $\quad R=2,89 \times 10^{-6} \times \frac{84,84 \times 10^{5}}{39,25 \times 10^{-2}}$

$$
=62,46 \Omega
$$

Sehingga didapat losses sebesar:

$$
\begin{aligned}
P_{\text {Losses }} & =3 \times 7.744 \times 62,46 \\
& =1.451 .070,72 \mathrm{~W}=1.451,070 \mathrm{~kW}
\end{aligned}
$$

\section{SIMPULAN}

Berdasarkan hasil perhitungan dan analisa dapat disimpulkan sebagai berikut :

1. Pada cuaca baik losses yang disebabkan oleh korona tertinggi pada suhu maksimum sebesar 755,92 kW dan losses terendah terdapat pada suhu udara minimum sebesar $702,47 \mathrm{~kW}$. Sedangkan effisiensi tertinggi terjadi pada suhu minimum sebesar $96,89 \%$. Dan effisiensi terendah terjadi pada suhu maksimum sebesar 96,62\%. Dengan adanya penurunan effisiensi maka losses yang terjadi akibat korona mencapai 3,38 \% .

2. Pada cuaca buruk losses yang disebabkan oleh korona tertinggi pada suhu maksimum sebesar 262,15 kW dan losses terendah terdapat pada suhu udara rata-rata sebesar 226,26 kW. Sedangkan effisiensi tertinggi terjadi pada suhu udara rata-rata sebesar 98,98\%. Dan effisiensi terendah terjadi pada suhu maksimum sebesar 98,82 \%.. Dengan adanya penurunan effisiensi maka losses yang terjadi akibat korona mencapai 1,02\%.

3. Losses yang terjadi akibat korona pada Saluran Udara Tegangan Tinggi (SUTT) $150 \mathrm{kV}$ GI Payakumbuh - GI Koto Panjang masih dalam keadaan stabil dimana belum melebihi Standar SPLN No.72 Tahun 1987 yakni sebesar 5\%.

4. Losses dapat diminimalisir dengan memperkecil tahanan kawat atau dengan menambah jumlah kawat per-phasa.

\section{DAFTAR PUSTAKA}

A.N. Afandi. (2011). A1-11 - A.N.AFANDI - EVALUASI RUGI DAYA SALURAN TRANMISI.pdf. In Rugi Daya Transmisi (Vol. 5, pp. A64-A68). elektro.um.ac.id/.../A111\%2520\%2520A.N.AFANDI\%2520\%2520EVALUASI\%2520R UGI\% $252 \ldots$

Alius, H. S., \& Hariyanto, N. (2014). Perancangan Sistem Transmisi Daya Listrik Bertegangan $150 \mathrm{KV}$ dan Berkapasitas 35 MVA di. 2(4), 250-259.

ANGGARA, W. (2019). Studi . Rugi Daya Listrik Akibat Korona Pada Saluran Udara Ungaran. 
Aykas, D. P. (2012). The Effect of Temperature, Lecithin Content, Voltage, Resistivity, Viscosity, and Surface Tension on Droplets $/ \mathrm{cm}^{2}$ During Electrostatic Spraying of Oil Copyright by Didem Peren AYKAS. 1-87.

Barrett, J. S., Davidson, G. A., Douglas, D. A., Hall, P. A., Reding, J. L., Seppa, T. O., Thrash, F. R., \& White, H. B. (1999). Limitations of the Ruling Span Method for Overhead Line. 14(2), 549-560.

Cimini, C. A., \& Fonseca, B. Q. A. (2013). Temperature profile of progressive damaged overhead electrical conductors. International Journal of Electrical Power and Energy Systems, 49(1), 280-286. https://doi.org/10.1016/j.ijepes.2012.12.015

Dewantara, M., Studi, P., Elektro, T., Teknik, F., \& Surakarta, U. M. (2018). Analisis rugirugi daya pada saluran transmisi tegangan tinggi $150 \mathrm{kv}$ dari gardu induk wonogiri sampai gardu induk wonosari. TK Electrical Engineering. Electronics Nuclear Engineering. http://eprints.ums.ac.id/60172/

Dewi, A. (2020). Studi Analisa Pengaruh Temperatur Dan Tekanan Udara Terhadap Rugi Daya Korona SUTT $150 \mathrm{kV}$. Jurnal Teknik Elektro ITP, 9(1), 47-53. https://doi.org/10.21063/jte.2020.3133909

Douglass, D., \& Thrash, F. (2012). Sag and Tension of Conductor. 1-42. https://doi.org/10.1201/b12056-19

Febry Johan Palasworo, A. W. (2019). Analisi Kontigensi Saluran Trasnmisi Pada Jaringan 150 kV Surabaya Selatan. Program Studi Teknik Elektro FT, UM-Surabaya, 53(9), 1689-1699.

Gorur, R. S., Cherney, E., De Tourreil, C., Dumora, D., Harmon, R., Hervig, H., Kingsbury, B., Kise, J., Orbeck, T., Tanaka, K., Tay, R., Toskey, G., \& Wiitanen, D. (1995). Protective Coatings For Improving Contamination Performance Of Outdoor High Voltage Ceramic Insulators. IEEE Transactions on Power Delivery, 10(2), 924-933. https://doi.org/10.1109/61.400837

Hariyadi, S. (2017). Analisis Rugi-Rugi Daya Dan Jatuh Tegangan Pada Saluran Transmisi Tegangan Tinggi $150 \mathrm{Kv}$ Pada Gardu Induk Palur - Masaran. Universitas Muhammadiyah Surakarta, 1, 20. https://docplayer.info/65922513-Analisis-rugi-rugidaya-dan-jatuh-tegangan-pada-saluran-transmisi-tegangan-tinggi-150-kv-pada-garduinduk-palur-masaran.html

Idris, A. R., \& Suyono, W. (2021). Analisis Pengaruh Pemasangan Counterpoise pada Tower Transmisi Saluran Udara Tegangan Tinggi $70 \mathrm{kV}$ Line Mandai-Pangkep. September.

Kosasih, G. B. (2017). Analisa rugi-rugi daya pada saluran transmisi tegangan tinggi $150 \mathrm{kV}$ pada gardu induk jajar - gondangrejo. Universitas Muhammadiyah Surakarta, 1-14.

Manik, M. L. (2013). Institut Teknologi - PLN. 11150331000034, 1-147.

Manullang, R. (2020). Analisa Rugi Rugi Daya Pada Penghantar Sutet 275 Kv Pangkalan 
Susu-Binjai.

Masarrang, R., Patras, L. S., Tumaliang, H., \& Transmisi, A. P. S. (2019). Efek Korona pada Saluran Transmisi Gardu Induk Tello Sulawesi Selatan. Jurnal Teknik Elektro Dan Komputer, 8(2), 67-74. https://doi.org/10.35793/jtek.8.2.2019.23980

Nadzirin, M., Nur, A., Dengan, K., \& Cincin, K. (2012). Analisis Medan Listrik Pada Plasma Korona Dengan Konfigurasi Cincin Bidang. Berkala Fisika, 13(4), 139-144.

Olsen, R. G., \& Edwards, K. S. (2002). A New Method for Real-Time Monitoring of HighVoltage Transmission Line Conductor Sag. IEEE Power Engineering Review, 22(6), 62-63. https://doi.org/10.1109/MPER.2002.4312315

Rusdi, S. (2019). Analisa Terbentuknya Korona Pada Saluran Kubicle Tegangan 20Kv Serta Pengaruhnya Terhadap Rugi-Rugi Daya. Lensa, 2(48), 14-21. https://ijc.ilearning.co/index.php/LENSA/article/view/1279

Saraswati, A., Sukmadi, T., Handoko, S., \& Belakang, L. (2012). Perhitungan Korona , Audible Noise Dan Radio Interference Pada Saluran Udara Tegangan Ekstra Tinggi 500 Kv Dengan Variasi Jarak Antar Kawat Dan Jarak Antar Sirkit. 1-9.

Vijayan, T., \& Patil, J. G. (2010). High-tension corona controlled ozone generator for environment protection. Journal of Physics: Conference Series, 208. https://doi.org/10.1088/1742-6596/208/1/012140

Yu, F. S., Lou, H. M., Gao, Y., \& Tian, X. F. (2013). Research of monitoring method of ice thickness for continuous slant spans of high-tension line. Applied Mechanics and Materials, 329, 148-152. https://doi.org/10.4028/www.scientific.net/AMM.329.148 